\title{
WHAT EXPERTS TELL ABOUT INTEGRATED MARKETING COMMUNICATION FOR EFFECTIVE BUSINESS PROMOTION AND SALE STRATEGY \\ Gunawan Widjaja ${ }^{1}$ \\ Universitas Krisnadwipayana, Bekasi, Indonesia \\ widjaja_gunawan@yahoo.com
}

\begin{abstract}
The expert's study about integrated marketing communications for promotion and sales strategies ineffective business activities is the main objective of this study. We address the core gap here through a literature review that addresses integrated marketing communications in sales and promotions in every business. We found data from more than 50 articles on the economics of marketing and business communications in sales and promotion. After we found the data, we studied it comprehensively under the phenomenological approach to finding findings or answers that were valid and believed to be valid. Because this study was carried out during the implementation of public mobility restrictions, we tried secondary data with a search system with the help of Google Scholar on several scientific publications such as Google book, Taylor, Sagepub, and Elsevier. Based on the existing data and discussion of the results, we conclude that a successful integrated marketing communication will establish a core message, emphasize the competitive advantage, address the right target market, and adapt the message to suit supporting media channels. The message is essentially the same across platforms, but the delivery mechanism varies.
\end{abstract}

Keywords: Marketing, Communication, Promotion, Expert Advice 


\section{INTRODUCTION}

Integrated marketing communication is a critical study in science and business practice in the global era to survive and win the tough competition (Villarreal, 2010; Sudarmo et al., 2021; Ariani, 2021). The study of facilitated publication correspondence usually understands how business strategies can be forwarded with comparative messages across all marketing media. The main reason for studying this kind of communication activity is that business people can influence many consumers with a significant part in it that can touch the level of understanding and connection (Rehman and Ibrahim, 2011). Usually, the part of communication used in the promotion business is small selling and significant selling. Low-time selling for the present situation combines publication, promotion, integrated communication, and utterly discreet communication to influence potential customers to the level of insight to partnering. Of course, solid sales, which combines personal selling, direct selling, and organizational development, are used to influence groups of prospects (Isaenko and Tarasov, 2014).

Business people need to understand and implement an integrated marketing communication strategy with an advanced framework as a joint publication correspondence is fully prepared to assist each exhibition in the association in achieving its business targets (Blakeman, 2018; Nuraini et al., 2021). They consider that this integrated communication is still like communication to forward a reliable marketing message so that every potential customer can receive and understand the information obtained when doing business transactions later. The integrated communication strategy is also essential in building the company's brand image. Because all the parts contained in a brand will be in the same way combined and will be more easily recognized by customers, so this kind of communication is also essential to drive the customer experience before they come to the transaction. In the high-level world of business, every group is not only looking for the thing or organization they need; they also need an experience that can truly satisfy their longing. Moreover, today's business is run in the context of competition, not only locally, nationally, and even internationally (Kitchen and Burgmann, 2010).

Besides having the option to reinforce a strong message in the group's character, this integrated communication is also ready to turn into an undeniable message and reason in business (Mihart, 2012). Implementing the integrated marketing communication strategy 
that we use as the core of the problem in this study is to have several objectives that underlie each cash supervisor in advancing an item with the correspondence of a joint exhibition. Join promoting correspondence is done to convey all messages in one way reliably. Until the end, the buyer understands and understands the message contained in an item (Barker, 2013). In the end, an integrated marketing strategy can develop a good effect on the brand or company. They are not limited to messages about a thing but things that clients will see better. Associated with these extraordinary characteristics are logos, content, and voice messages that can be conveyed well, so they need to create a brand that is easier to know and review by the broader consumer community (Wheeler, 2017).

According to Finne and Grönroos, (2009) creating a structured and integrated comics strategy helps build good customer inclusion. After all, based on the subtle developments in the high-level world, buyers are not only looking for things subject to quality and organization. Clients moreover need things that have a picture that fits their needs. With messages of valuables in unified follow-up correspondence, buyers who have experienced goods can similarly choose how goods messages can be given to individuals as a general rule to make good profits for the association (Luxton et al., 2015). Various examples of integrated marketing communications will be the subject of this study. We chose this study considering that such communication is beneficial for marketing managers and product business promotions, but there are also other benefits of integrated marketing communication, highlighting competitive advantages that can drive high sales. For companies that tend to be minor, like startups, an integrated marketing communications strategy helps quickly draw customers to the buying stage. Based on this evidence, we are interested in presenting the findings in the next section (Kitchen and Burgmann, 2010).

\section{RESEARCH METHOD}

The primary goal of this research is to find out what professionals have learned about integrated marketing communications for unsuccessful company promotion and sales tactics. We bridge the gap here by doing a literature study on integrated marketing communications in sales and promotion in all businesses (Damgaard et al., 2001). We gathered information from over 50 publications on marketing economics and corporate communications in sales and promotion. After we have found the data, we use a 
phenomenological method to examine it thoroughly to discover results or responses that are both valid and perceived to be genuine. Because this study was performed at the introduction of public mobility limitations, we used secondary data from Google Scholar on many scientific papers published in the past ten years, such as Google book, Taylor, Sagepub, and Elsevier, to bring our results up to date. In reporting and evaluating data, we follow the direction of qualitative research (Doz, 2011).

\section{RESULTS AND DISCUSSION}

This section will describe and discuss the results of a particular study on several papers published in high-impact journals interested in discussing how the need for integrated marketing communications is to market business products in the current digital era.

\section{Publish promotions continuously}

Promoting correspondence in the advanced economy can hardly be underestimated, and the goods are constant. The timing of this change is visible here, reporting on the progress by organizations and offices from an emphasis on the independent custom correspondence component to where all components are combined. The combination is driven by innovative advances, media discontinuity, market demassification, and severe stressors. According to Kitchen and Burgmann, (2010) incorporating advertising communications is one type of progress completed by sensitive sales that must be published. Because in it, advancing helps show the superiority of an object and understanding its position, which deviates from various things. Overall, publications can be used in various media, such as TV, online media, radio, and others.

Likewise, Amin and Priansah, (2019) study said that marketing communication increases business potential. In this case, they raised the tourism business in Indonesia with the display model of the Curug Putri Palutungan tourist area with the most critical social and holiday goals in the Kuningan area, West Java. Several scaffoldings were built to facilitate guest and travel access to the holiday district, recently isolated by various streams. One strategy to support the potential of large travelers is through correspondence with the Department of Youth, Sports, and Tourism of the Republic of Indonesia. Camilleri, (2018) 
also reported a similar study, which successfully integrated marketing communications in travel marketing journals.

In the same way, publications are also crucial for providing buyers with data about a brand. The basic model is to exhibit informative publications; the remarkable progress reliably gives the impression and desire for reliable data to emerge in the client's character. For this reason, the findings of Naumovska and Blazeska, (2016) with a study of correspondence-based advertising models display coordinated. The featured and hypothetical correspondence industry is facing rapid changes according to the concerns of businesses and societies worldwide. The most executed instrument for displaying correspondence - promotes, loses its power to attract interchanges; clients become overly publicized and immune to the usual increase in publications. Promoting business products because of the extensive single-way correspondence communication tools so far have not been as successful as before, so currently cannot fulfill the task of driving the promotional mix tools. A similar study was also conducted by Juska, (2017) who said that integrated marketing communication could be in the form of advertising and promotion with the help of digital technology tools.

\section{Online promotion}

Following the views is from Papasolomou and Melanthiou, (2012) who said that online media is the best new companion for marketing advertising today globally. The success of promotional efforts and coordination of advertising correspondence is influenced by the exciting use of the progress of data correspondence, including the almost evenly distributed use of the InternetInternet in every community, both in cities and remote areas. With online media on the rise, some might say that traditional performance rehearsals, as far as we know, are going to be eliminated. The essence of this exploration is to distinguish and talk about the development of ubiquitous online media and investigate the expected effect on promoting practice.

Likewise, the views of Bara et al., (2021) were an essential part. They said that the effectiveness of advertising marketing in print media during the Covid 19 pandemic in the Mandailing Natal Region was increasingly being abandoned by readers. Experts at the University of South Africa have studied the impact of the Covid-19 pandemic on advertisements displayed in paper media at Mandailing Natal. The test uses survey 
speculation as a condensation for Stimulus-Organism-Response (SOR), which affects how human personality responds to the design of online communication media, which is increasingly in demand by the community today. It turns out that the digital online problem in the current era has become an important issue that beats print media even in remote areas (Yamin, 2017). He said that the impact of digital marketing as an effective means of marketing communication is seen in the behavior of consumers in Bangladesh.

Continuation of online advertising, Melović et al., (2020) said the effect of progressive changes and computerized advertising on the advancement of brands, situations, and e-business in Montenegro. The most well-known approach to measuring the impact of computerized promotions is Google Analytics, followed by social network user engagement and engagement rates. The length of time in which advanced advertising is used is critical and greatly influences the decisions of computerized props, how exhibitions are estimated, and supervisors' views on the adequacy of their costs. Informal organization is the most commonly used type of computerized advertising in the market under study, and Google research is the most widely recognized approach to measuring the impact of the continued promotion. Findings of internet-assisted advertising or e-commercial are also discussed by Al Khattab et al., (2015) with the theme of the study of integrated marketing communication and its impact on customer behavior.

Additionally, as customer care is fundamental for promoting, publicizing ought to be moreover conceivable directly. This system is one way for likely customers to become more familiar with association or brand more. This method ought to be done pleasantly and exuberantly, to have the choice to give a positive impression to customers and welcome them to return. Promoting is a sort of facilitated displaying correspondence to extend purchaser trust in the picture and things.

\section{Advancement through sales promotion}

Advertising is one of the most remarkable advances in product offerings in an integrated marketing communications strategy. The simple model is limit and easy; each overall financial manager will do free one-get-one promotion or discounted food prices with the smallest pre-determined installments. Ofosu-Boateng, (2020) findings examined the impact of sales promotion and relationship marketing on customer retention in the Telecommunications industry in Accra, Ghana. Their study examined the impact of 
transaction progress and relationship promotion on client maintenance in a telecommunications business in Accra, Ghana. A convenience check strategy is used to structure the information of a sample of 150 telecommunication company clients in the city that investigated findings show rewards as the most positive, draws and challenges as large, value limits as less than ideal, and the use of tests as the least positive method of progressing transactions to retain clients. A similar study is also proven by Oyeniyi, (2011) with the theme of sales and promotions on prospective consumers loyal to the telecommunications industry companies in Nigeria.

The following study by Alimpic, (2014) also proves the adequacy of transaction progress instruments from the consumer's point of view. The motivation behind this exploration is to understand how effective the transaction progress method is in causing changes in client behavior. Information is broken down using two measurable/econometric strategies: ANOVA and T-test to achieve this goal. As per discovery, limits and extra packages are the most productive method of increasing offers to inspire the best response from clients.

\section{Business promo through events and experience}

Findings from Briciu and Briciu, (2020) on participatory culture and the tourist experience convey the ease of getting information about critically innovative marketing and tourism through YouTube. This investigation uses an exploratory configuration by selecting the initial 100 pieces developed by YouTube and taking the topic of Bran Castle (otherwise Dracula Castle) and Braşov, the location of Transylvania Romania, which is transferred by various client classifications. This shows that YouTube is considered essential to the travel industry as it gives travelers a down action and helps them after meeting them. Similar findings were also made in Indonesia Mahardika, (2021) how to design a motion graphic infographic video as a promotional media for Pacitan beach tourism destinations through Youtube.

Next is the proof of Jackson, (2013) which discusses how to promote and promote opportunities from both a theoretical and practical point of view. His available findings introduce students to the speculations, ideas, and abilities essential to effectively advancing an event. To successfully advance an event, get advertising, but on the other hand, understand that it is not just shoppers that make up the crowd: the various publics that may 
not participate can fundamentally affect the achievement of an event. His findings are centered around the way current communications explicitly relate to the program's business. It presents marketing methods, buyers, advertising reaction publics, and how to use the web to advance marketing communications. It coordinates a wide range of global contextual investigations from limited scope opportunities to significant opportunities to help demonstrate how hypotheses can be applied practically. The same thing was also done in Indonesia (Chrismardani, 2014) with the theme "Integrated Marketing Communication: Implementation for MSMEs."

It is still about business promotion via events where the findings of Da Silva and Las Casas, (2017) have proven how sports fans are tempted by the way advertising is handled by sports stars through the presence of sports stars. This evidence emerges as a reason to examine fan pretense as buyers in advertising methodology in pro sports clubs. This research is essential for an assignment that will provide several more authentic papers that will utilize the fan's point of view as one of the centers of interest to investigate sports clubs in the city of São Paulo, Brazil. In understand sports fans, five points are made to contextualize them: (I) Outline of sports fans to clarify what fans are implying; (ii) Loyalty to and participation in sporting events; (iii) Consumers as customers to talk about what they like to burn; (iv) 'new' collaborations between fans and groups; (v) and gaming fans as a source of income, what instruments do sports clubs use to earn money from their fans? The same thing was also proven by Chen et al., (2017) who prepared a sporting event as a promotional strategy event for the 2009 World Games.

\section{Deals through direct selling}

Create and carry out a planned promotional correspondence process that includes promoting a mixed philosophy to be presented and carrying out different efforts that have been chosen, according to Ruswanti et al., (2019). They evaluated the impact of advertising, sales promotion, personal selling, and direct selling on vegetable purchase intent in West Jakarta retail. The body needs ordinary food to be consistently strong, regardless of expense. Buyers will eat non-ordinary veggies daily since they are more costly than common vegetables. This study aims to see whether common veggies can be introduced to regular customers via publicity, bargaining, individual selling, and direct 
marketing. Similarly, research by Pearson, (2016) found that generating economic value from customer connections direct strengthens brands.

The study of Hanifah et al., (2017) improves strategies through direct selling to increase premium spending in utilizing lodging administration. The motivation behind this research is to find out how to progress through direct selling in increasing buyer premium using the administration of Grand Cempaka Inn Puncak Bogor. This examination uses a clear subjective strategy by conducting information recovery methods and direct perception. The validity of the information performs the triangulation procedure. Conversations about progress lead to simple offers, making product presentations, (speed of) progress, how fast for future clients to see, during time spent on promotion through direct selling (del Mar Alonso-Almeida and Bremser, 2013).

Furthermore, Habel et al., (2021) examine how social selling shapes the advancement of internet salesman business channels from individual to web-based sales. Many business-to-business organizations anticipate that their salespeople should leverage online business channels to clients as an elective approach to buying in the computerized economy. However, salespeople are often reluctant to follow this method, which is rarely analyzed by academic research despite its functional significance. Content creators develop a hypothetical structure that describes the critical determinants of online retail channel salesman progress. The same thing was done by Tarkiainen, (2020) who tested how to handle the benefits of selling socially in a company that was just a startup.

Likewise, the findings of Widodo and Oktaviani, (2018) are promoting communication strategies using Instagram to increase sales achievement. The use of webbased media is increasing. Inevitably, many social orders use online media as a business. Exercise can be assessed more broadly. Racingmerch chooses the Instagram web-based media type as a showing tool. The audit strategy used is qualitative. Information gathering procedures were assisted through inside and outside interviews and direct perception of the advertising correspondence methodology. Similar research also came from Swani et al., (2014) with his study "Should tweet differ for B2B and B2C? An analysis of Fortune 500 companies.

Cochran looked at the promotion method of direct selling as well (2021). According to them, Molly's Mary Kay journey is the road to company ownership via direct selling. 
Molly Williamson, a Mary Kay Independent Sales Director, discusses her decision to pursue Mary Kay full-time in this instance. Mary Kay is a fast-growing network of top skincare and beauty goods that offers independent entrepreneurs business possibilities. This case emphasizes direct offers, including terminology to distinguish direct selling from the pyramid and Ponzi schemes, as well as Mary Kay opportunity diagrams. They control, verify, and evaluate all coordinated advertising communication thoughts to determine the viability of the task. Consequently, the findings will reveal whether or not the technique employed is suitable for the situation.

\section{Reasons for integrated marketing communications strategy}

Several steps must be taken to achieve the best results in implementing a coordinated advertising communication methodology, to be more specific, for example, wanting to separate an advertising marketing situation, the method is to examine the advantages and disadvantages of using certified data, understand the signs of the problem, and also find actions. David and Martina, (2011) believe through situational assessment that the process of looking at an association and its opposites depend on the size and share of the market, the history of the bargain, including costs and benefits, use of promotions, nature, and type of customers and it is only a hint of something bigger. (Key and Czaplewski, 2017).

Use genuine reviews; situational checks describe anticipated customers, surveys that project a turn of events, assess competitors, and make reasonable business evaluations. It remembers focusing on a clear goal, being alert, and recognizing the parts that help or hinder objections (Suzuki, 2017). The business makes the promotion state test. Organize a state check; businesses must consider the difficulties and patterns that may affect the company's promotional program, be prepared for the financial cycle, and check the current status of business opponents. Once marketing has identified these dangers and loopholes, businesses need to provide a realistic idea of reacting to them.

Separate the information provided, one way is to understand the delayed effects of the examination on each response from obtaining information, the stages in sending information, and the information media used. Market inspection is the most widely recognized method of gathering information about markets within an industry (Scoboria and Fisico, 2013). The company check considers the components of the market and what is 
generally essential to potential customers. However, examining the market may seem confusing, but it is the real hope needed to lead a business to progress. These are the seven stages of directing market inspection: Determine sales motivation, research business conditions, identify company's objective clients, understand company opposition, collect additional information, analyze company information, conduct investigations, what promotion procedures are investigated (Verbeke et al., 2011).

Market analysis and investigation is a survey methodology and introduces different internal and external variables and conditions in a particular specialty. Then make a financial plan for spending, see if capital is well accessible, or determine market fragments, targeted market areas, and the actual expenditures needed in determining the publication system (Wiid and Diggines, 2010). The following are six stages of developing an advertising financial plan as a feature of the company's display plan, such as knowing sales channels, knowing operating costs, setting marketing budgets based on business objectives, positioning marketing as an investment, considering growth stages, understanding current and future trends (Fahy and Jobber, 2019).

A promotional spending plan is a measure of additional spending to advertise a product or service. Expenditures in promotion spending will be determined by the mission and the media to be used. Some previous exploration will be essential for the quote to make as much sense as one might expect. They are fostering an integrated promotional correspondence program by taking all advertising correspondence programs. The most effective method to develop an integrated marketing communications plan, identify customers. The initial stage in developing an interchange plan is deciding who needs the mission to achieve, setting clear goals (Coll et al., 2011). While fostering coordinated display correspondence, companies can offer such as creating an integrated marketing communications strategy. Understand target customers, prepare budget plans, identify unique selling propositions, define marketing communication methods, maintain consistent brand elements, list key success metrics, execute, test, and iterate (Blank and Dorf, 2020).

\section{CONCLUSION}

We can conclude that our study has provided an answer which is the main objective of getting advice from experts on marketing business communication strategies in handling communication with prospective customers. First, we talk about understanding what 
integrated marketing communication with a straightforward understanding is. So, the answer is that integrated marketing is the process of bringing together all aspects of marketing communications such as advertising, PR, and social media and using a mix of individual media, channels, and tactics to deliver a seamless, customer-centric experience.

As we mentioned earlier, Integrated Marketing communications can be used in harmony with the five main communication tools. These are advertising, direct marketing, internet marketing, sales promotion, and public relations. Experts say the core of our findings is how marketing communication can be achieved with the help of the internet or digital communication-promoting while selling at a slightly tilted price than usual. Furthermore, promotions and advertising by experience and events were essential. Furthermore, it can also be through direct sales to consumers, with several reasons for an integrated marketing communication strategy. We hope that the results of this study can contribute to the development of science and practice for those interested in this field of study.

\section{REFERENCES}

Al Khattab, S.A., As'ad, H., Zaidan, G.M., (2015). E-Integrated Marketing Communication and its impact on customers' attitudes. Am. J. Ind. Bus. Manag. 5, 538.

Alimpic, S., (2014). The effectiveness of sales promotion tools: customers' perspective. Актуальні Проблеми Економіки 142-151.

Amin, M., Priansah, P., (2019). Marketing Communication Strategy To Improve Tourism Potential. Bp. Int. Res. Crit. Inst.-J. BIRCI-J. 2, 160-166.

Ariani, Z., (2021). Policy Strategy of Rural Agribusiness Development Program for Agricultural Sharia Micro Economic Development. Indones. Interdiscip. J. Sharia Econ. IIJSE 4, 50-61. https://doi.org/10.31538/iijse.v4i1.1151

Bara, A., Affandi, F., Farid, A.S., Marzuki, D.I., (2021). The Effectiveness of Advertising Marketing in Print Media during the Covid 19 Pandemic in the Mandailing Natal Region. Bp. Int. Res. Crit. Inst.-J. BIRCI-J. 879-886.

Barker, R., (2013). Strategic integrated communication: An alternative perspective of integrated marketing communication? Communicatio 39, 102-121.

Blakeman, R., (2018). Integrated marketing communication: creative strategy from idea to implementation. Rowman \& Littlefield.

Blank, S., Dorf, B., (2020). The startup owner's manual: The step-by-step guide for building a great company. John Wiley \& Sons. 
Briciu, A., Briciu, V.-A., (2020). Participatory culture and tourist experience: promoting destinations through YouTube. Strateg. Innov. Mark. Tour. Springer Proc. Bus. Econ. Kavoura Kefallonitis E Theodoridis P Eds 425-433.

Camilleri, M.A., (2018). Travel marketing, tourism economics and the airline product: An introduction to theory and practice. Springer.

Chen, Y., Chu, C.N., Sun, H.M., Chen, R.-S., Tu, M., Lin, S.C., (2017). Using case-based reasoning method to design a return merchandise authorization system for supply chain management in Internet of Thing, in: 2017 IEEE 17th International Conference on Communication Technology (ICCT). IEEE, pp. 1462-1466.

Chrismardani, Y., (2014). Komunikasi pemasaran terpadu: implementasi untuk UMKM. Neo-Bis 8, 179-189.

Coll, R.K., Eames, C.W., Paku, L.K., Lay, M.C., Hodges, D., Bhat, R., Ram, S., Ayling, D., Fleming, J., Ferkins, L., (2011). An exploration of the pedagogies employed to integrate knowledge in work-integrated learning.

Da Silva, E.C., Las Casas, A.L., (2017). Sport fans as consumers: An approach to sport marketing. Br. J. Mark. Stud. 5, 36-48.

Damgaard, T., Freytag, P.V., Darmer, P., (2001). Qualitative methods in business studies. Emerald Group Publishing Limited.

David, S., Martina, R., (2011). Marketing communications mix of universitiescommunication with students in an increasing competitive university environment. J. Compet. 3, 58-71.

del Mar Alonso-Almeida, M., Bremser, K., (2013). Strategic responses of the Spanish hospitality sector to the financial crisis. Int. J. Hosp. Manag. 32, 141-148.

Doz, Y., (2011). Qualitative research for international business. J. Int. Bus. Stud. 42, 582590.

Fahy, J., Jobber, D., (2019). EBOOK: Foundations of Marketing, 6e. McGraw Hill.

Finne, \AAke, Grönroos, C., (2009). Rethinking marketing communication: From integrated marketing communication to relationship communication. J. Mark. Commun. 15, 179-195.

Habel, J., Alavi, S., Linsenmayer, K., (2021). From personal to online selling: How relational selling shapes salespeople's promotion of e-commerce channels. J. Bus. Res. 132, 373-382.

Hanifah, E.N., Sukarelawati, S., Agustini, A., (2017). Metode promosi melalui direct selling dalam meningkatkan minat konsumen menggunakan jasa hotel. J. Komun. 3.

Isaenko, E.V., Tarasov, A.S., (2014). Automobiles selling organizations' marketing communications assessment directions. Life Sci J 11, 239-242.

Jackson, N., (2013). Promoting and marketing events: Theory and practice. Routledge. 
Juska, J.M., (2017). Integrated marketing communication: advertising and promotion in a digital world. Routledge.

Key, T.M., Czaplewski, A.J., (2017). Upstream social marketing strategy: An integrated marketing communications approach. Bus. Horiz. 60, 325-333.

Kitchen, P.J., Burgmann, I., (2010). Integrated marketing communication. Wiley Int. Encycl. Mark.

Luxton, S., Reid, M., Mavondo, F., (2015). Integrated marketing communication capability and brand performance. J. Advert. 44, 37-46.

Mahardika, V.P., (2021). Perancangan Video Motion Graphic Infografis sebagai Media Promosi Destinasi Wisata Pantai Pacitan Melalui Youtube (PhD Thesis). Institut Teknologi Sepuluh Nopember.

Melović, B., Jocović, M., Dabić, M., Vulić, T.B., Dudic, B., (2020). The impact of digital transformation and digital marketing on the brand promotion, positioning and electronic business in Montenegro. Technol. Soc. 63, 101425.

Mihart, C., (2012). Modelling the influence of integrated marketing communication on consumer behaviour: an approach based on hierarchy of effects concept. ProcediaSoc. Behav. Sci. 62, 975-980.

Naumovska, L., Blazeska, D., (2016). Public relation based model of integrated marketing communications. UTMS J. Econ. 7, 175-186.

Nuraini, N., Sarkum, S., Halim, A., (2021). Analysis of Company Capability, Supply Chain Management of Competitive Advantage, and Company Performance. Indones. Interdiscip. J. Sharia Econ. IIJSE 4, 87-104. https://doi.org/10.31538/iijse.v4i1.1463

Ofosu-Boateng, I., (2020). Effect of Sales Promotion and Relationship Marketing on Customers' Retention in the Telecommunications Industry in Accra, Ghana. Br. J. Manag. Mark. Stud. 37-54.

Oyeniyi, O., (2011). Sales promotion and consumer loyalty: A study of nigerian tecommunication industry. J. Compet. 66-77.

Papasolomou, I., Melanthiou, Y., (2012). Social media: Marketing public relations' new best friend. J. Promot. Manag. 18, 319-328.

Pearson, S., (2016). Building brands directly: creating business value from customer relationships. Springer.

Rehman, S. ul, Ibrahim, M.S., (2011). Integrated Marketing Communication and Promotion (SSRN Scholarly Paper No. ID 2383065). Social Science Research Network, Rochester, NY. 
Ruswanti, E., Hapsari, N.P., Januarko, M.U., Kusumawati, M.D., (2019). Analysis Advertising, Sales Promotion, Personal Selling And Direct Selling On Purchase Intention Vegetables In Retail West Jakarta. Adv. Econ. Bus. Manag. Res. 10, 657662.

Scoboria, A., Fisico, S., (2013). Encouraging and clarifying "don't know" responses enhances interview quality. J. Exp. Psychol. Appl. 19, 72.

Sudarmo, Nugraha, M.S., Mardhiah, R. I.liow, F.E., Aslan, (2021). The Identification of Online Strategy Learning Results While Students Learn from Home During the Disruption of the COVID-19 Pandemic in Indonesia. J. Contemp. Issues Bus. Gov. 27, 1950-1956. https://doi.org/10.47750/cibg.2021.27.02.205

Suzuki, T., (2017). TPM in process industries. Routledge.

Swani, K., Brown, B.P., Milne, G.R., 2014. Should tweets differ for B2B and B2C? An analysis of Fortune 500 companies' Twitter communications. Ind. Mark. Manag. 43, 873-881.

Tarkiainen, M., (2020). How to take advantage of social selling in a small company.

Verbeke, W., Dietz, B., Verwaal, E., (2011). Drivers of sales performance: a contemporary meta-analysis. Have salespeople become knowledge brokers? J. Acad. Mark. Sci. $39,407-428$.

Villarreal, R., (2010). Integrated Marketing Communication Strategy. Wiley Int. Encycl. Mark.

Wheeler, A., (2017). Designing brand identity: an essential guide for the whole branding team. John Wiley \& Sons.

Widodo, Y., Oktaviani, I.D., (2018). Marketing Communication Strategy Using Instagram to Increase The Selling Achievement, in: International Conference on Applied Science and Engineering (ICASE 2018). Atlantis Press, pp. 65-67.

Wiid, J., Diggines, C., (2010). Marketing research. Juta and Company ltd.

Yamin, A.B., (2017). Impact of digital marketing as a tool of marketing communication: a behavioral perspective on consumers of Bangladesh. Am. J. Trade Policy 4, 117122. 